\title{
ВОЗРАСТНАЯ ВАРИАБЕЛЬНОСТЬ ГИСТОЛОГИЧЕСКОЙ СТРУКТУРЫ МОЛОЧНОЙ ЖЕЛЕЗЫ У МОЛОЧНОГО И НЕМОЛОЧНОГО СКОТА В ЗАВИСИМОСТИ ОТ ПОРОДЫ И ПРОИСХОЖДЕНИЯ
}

\author{
М.Б. УЛИМБАШЕВ1, О.О. ГЕТОКОВ², В.В. КУЛИНЦЕВ1, Р.А. УЛИМБАШЕВА²
}

Для большинства молочных пород в процессе селекции практически достигнут биологический порог продуктивности. Кроме того, с развитием высокомеханизированных и автоматизированных технологий производства молока повысились требования к отбору животных по приспособленности к таким условиям, в частности по состоянию вымени. Поэтому дополнительным резервом может быть совершенствование молочного скота и повышение качественных показателей молока на основе углубленных исследования морфологических, функциональных особенностей и физиологии молочной железы. Наиболее информативными представляются данные о структуре и функции молочной железы у видов с высокой исходной молочностью и высокими показателями качеств в сопоставлении с наиболее распространенными породами крупного рогатого скота. Однако в научной литературе отсутствуют сведения о сравнении гистоструктуры молочной железы коров и ячих. Результаты, представленные нами в настоящем исследовании, восполняют этот пробел. Изучение гистоструктуры молочной железы провели в двух хозяйствах в Кабардино-Балкарской Республике: в первом (СПК им. Ленина) - на коровах черно-пестрой и бурой швицкой пород, их помесях с голштинами $F_{1}$ и $F_{2}$; во втором (OOO «Эльбрус Агроинвест») - на швицах местной популяции и ячихах, завезенных из Тувы и Киргизии. Микроструктуру молочной железы изучали на образцах размером $2 \times 3$ см, отобранных между основанием молочной цистерны и основанием всей доли вымени по линии, проходящей через середину соскового канала и молочной пазухи правого переднего соска. В молочной железе помесных коров (голштины $\times$ швицы) диаметр альвеол был наибольшим и составил у коров 3-го отела 119 мкм, что на 6,2-3,7 \% выше аналогичного показателя у сверстниц из других групा при высокой доверительной вероятности (Р > 0,999). Наименьшим диаметром жировых клеток (68,3 мкм) характеризуются коровы черно-пестрой породы, наибольшим - полукровные помеси голштины $\times$ швицы 3-й лактации, все остальные группы занимали промежуточное положение. Наибольшее увеличение диаметра жировых клеток с возрастом происходит в молочной железе помесей голштины $\times$ черно-пестрый скот в $F_{2}$, у которых этот показатель изменяется от 68,6 мкм у первотелок до 77,3 мкм у животных 3-го отела. Следовательно, улучшенные голштинами животные по степени развития и величине структурных элементов, важных для секреции молока (размер молочных альвеол и диаметр жировых шариков), превосходят сверстниц бурой швицкой и черно-пестрой пород. Установлено, что по диаметру альвеол животные бурой швицкой породы местной популяции превосходили коров-ячих в среднем на 9,1-11,3 мкм (независимо от региона завоза). При этом диаметр жировых клеток у ячих был в среднем на 4,5-5,4 мкм больше, чем у сверстниц швицкой породы. Таким образом, сравнение молочной железы у бурого швицкого скота и ячих, завезенных из Тувы и Киргизии, выявило следующие характерные особенности: у швицев местной популяции отмечается увеличение числа клеток железистого эпителия, диаметра альвеол, толщины магистральных тяжей, тогда как у ячих из разных популяций, напротив, повышено содержание жировой ткани при уменьшении диаметра жировых клеток и толщины междольковых тяжей. Для сравнения были выполнены исследования молочной железы еще у одного вида животных - у коз разного происхождения. Показано, что особи зааненской породы превосходят животных местной популяции по развитию и биомеханическими свойствами молочной железы.

Ключевые слова: коровы, яки, козы, генотип, молочная железа, гистоструктура, альвеолы, жировые клетки, соединительная ткань, тяжи.

Изучение особенностей физиологии молочной железы коров имеет важное значение в связи с проблемой повышения молочной продуктивности (1). Кроме того, такие исследования углубляют фундаментальные представления о биологии этого органа, определяющего развитие млекопитающих $(2,3)$. В России начало таким исследованиям было положено Е.Ф. Лискуном, который в 1912 году описал существенные различия в гистоструктуре вымени у молочного (красная степная и ярославская породы) и рабочего (серого степного) скота (4).

Форма, размер, состояние вымени определяют устойчивость коров к маститам, надои и продолжительность продуктивного периода $(5,6)$. 
Так, в Нидерландах ущерб от одного случая клинической формы мастита составил от 164 до 235 евро в зависимости от месяца лактации, а в целом по стране мог достигать 100 млн евро (7). Заболеваемость молочной железы на молочных предприятиях США в течение года достигает $51 \%$, а затраты на лечение оцениваются в среднем в 2 млрд долларов. Частота клинической формой мастита в Великобритании несколько ниже - 32-38 \%, тогда как в Германии составляет до $60 \%(8,9)$. Заболеваемость маститом в хозяйствах России составляет от 10-20\% до 70-80\%. Экономический ущерб, наносимый этим заболеванием молочному скотоводству, составляет 150-200 млрд руб. в год $(10,11)$. На определенную зависимость между развитием патологии молочной железы у коров и формой соска и вымени указывали J. Mitev с соавт. (12) и R. Asadpour с соавт. (13). В последние десятилетия породный состав крупного рогатого скота значительно изменился в сторону разведения обильномолочных пород, что сопровождалось увеличением частоты ряд патологий, в том числе мастита. Применение диагностики на основе определения количества соматических клеток в молоке и ультразвукового сканирования позволили снизить заболеваемость маститом, повысить продуктивность и увеличить сроки использования коров в хозяйстве (14).

Эндокринные изменения, связанные с беременностью, стимулируют обширную клеточную пролиферацию в молочной железе, которая продолжается на ранних стадиях лактации. Затем клеточная популяция заметно уменьшается до завершения инволюции (15). При изучении SP-клеток молочной железы выяснилось, что они представляют собой недифференцированную субфракцию эпителиальных клеток. SP-клетки сохраняют потенциал для дифференциации in vitro в клоны, типичные для молочной железы, и в нормальные лобулярные и протоковые структуры in vivo. Изучение и идентификацию стволовых клеток молочной железы $(16,17)$ выполняли с их предварительным мечением и трансплантацией в молочную железу для последующего анализа локализации (18).

Молочная железа - один из наиболее лабильных и легко изменяющихся органов у животных. Причины, вызывающие эти вариации, весьма разнообразны и зависят от породной принадлежности $(19,20)$, возраста, месяца лактации (19), стельности, условий кормления и содержания, технологии доения коров (21-24). При этом существенное влияние на количество секретируемого молока оказывает центральная нервная система, органы пищеварения, дыхания, внутренней секреции и в большой степени интенсивность кровообращения (25-27).

Для улучшения продуктивных и технологических качеств отечественного скота, наряду с внутрипородной селекцией, для скрещивания с отечественным скотом часто используется генофонд лучших зарубежных пород. Гистологические исследования молочной железы у айрширского скота показали, что у дочерей быков финского происхождения железистая ткань вымени наиболее развита: число альвеол на $1 \mathrm{Mм}^{2}$ у них составило 27,3 шт., в то время как у дочерей канадского происхождения - 25,1 шт. при диаметре соответственно 125,1 и 123,5 мкм (28). У телок отечественной костромской породы в 16-месячном возрасте выявлены различия в долях вымени по морфологическому строению железистой и соединительной тканей (неодинаковые типы ветвления протоковой системы). Установлено наилучшее соотношение железистой и соединительной ткани (соответственно 38,1 и 61,9 \%) в четвертях с магистральным типом выводной системы (29).

Сходные особенности отмечаются и у видов немолочного скота. У 
ярок в 6-месячном возрасте размер зачатка железистой ткани в молочной железе составил 39,5 мкм (30). У новорожденных ярок железистая ткань локализована в центре жировых долек, имеет вид эпителиальных зачатков в форме островков (31). В молочной железе новорожденных ярок соединительная ткань превалирует над железистой (соотношение в среднем 0,7:1,0). У взрослых овец наблюдается похожая тенденция, при этом доля соединительной ткани в молочной железе увеличивается и достигает $65 \%$, тогда как железистой - 35 \%. В период суягности в молочной железе овец активизируется развития железистой ткани.

Для молочной железы коз зааненской породы в период новорожденности характерно преобладание жировой ткани, ограниченной соединительнотканной стромой в виде тяжей. Паренхима представлена в виде долек, разделенных зонами соединительной ткани. Непосредственно в дольке локализована жировая ткань с небольшим количеством железистой ткани в виде эпителиальных зачатков. У годовалых коз зааненской породы на жировую ткань приходится 33,5 \%, на железистую - 41,5 \% , на соединительную - 25,0 \%. Считается, что у коз в этом возрасте молочная железа полностью сформирована (32).

Исследований морфологии и гистологического строение молочной железы ячих в литературе мы не нашли.

Известно, что при полной реализации генетического потенциала у животных регистрируют заболевания, вызванные нарушением обмена веществ, и снижение устойчивости к факторам окружающей среды $(33,34)$. Кроме того, развитие высокомеханизированных и автоматизированных технологий в молочном скотоводстве повышают требования к отбору животных по приспособленности к таким условиям, в частности по состоянию вымени $(35,36)$.

В Кабардино-Балкарской Республике работа по селекционному совершенствованию бурого швицкого и черно-пестрого скота проводится с привлечением генофонда голштинского скота черно-пестрой масти. При этом данные о влияния скрещивания с голштинами на структурные и функциональные особенности молочной железы коров отсутствуют. Также нет сведений о гистологическом строении и биомеханических свойствах молочной железы самок яков и коз, разведение которых целесообразно с учетом региональных природно-климатических факторов.

В настоящем исследовании мы впервые представляем сравнительные данные о гистоструктуре молочной железы у коров бурой швицкой породы, их помесей с голштинами (разные генерации), ячих, завезенных из Тувы и Киргизии, и коз, разводимых в республике. Полученные результаты дополняют существующие представления о структурной и функциональной организации этого органа млекопитающих.

Целью работы было гистологическое исследование особенностей строения молочной железы у животных разных видов и пород в зависимости от происхождения и типа использования.

Методика. Исследования проводили с 2012 по 2017 год. В СПК им. В.И. Ленина (Урванский р-н, Кабардино-Балкарская Республика) были сформированы 6 групп коров по 5 гол. в каждой. В I группу вошли животные швицкой породы, во II - помесные коровы (голштины $\times$ швицы) $\mathrm{F}_{1}$, в III - их сверстницы $\mathrm{F}_{2}$, в IV - коровы черно-пестрой породы, в V полукровные коровы (голштины $\times$ черно-пестрый скот) в $\mathrm{F}_{1}$, в VI - их сверстницы (кровность $1 / 4$ черно-пестрый скот $+3 / 4$ голштины) в $\mathrm{F}_{2}$. В ООО «Эльбрус Агроинвест» (село Безенги, Черекский р-н, КабардиноБалкарская Республика) для исследования отобрали по 5 животных из по- 
головья ячих (популяции, завезенные из Тувы и Киргизии) и коров бурой швицкой породы местной популяции. Козы зааненской породы (3 гол.) содержались в фермерском хозяйстве «Сарский» (Майский р-н, Кабардино-Балкарская Республика), местные козы (3 гол.) - в личных хозяйствах (село Арик, Терский р-н, Кабардино-Балкарская Республика). Все хозяйства благополучны по инфекционным и инвазионным заболеваниям.

Для гистологического исследования отбирали образцы ткани размером $2 \times 3$ см между основанием молочной цистерны и основанием всей доли вымени по линии, проходящей через середину соскового канала и молочной пазухи правого переднего соска. Отобранные образцы консервировали в $10 \%$ растворе формалина в течение 24 ч и переносили в $5 \%$ раствор для постоянного хранения. Срезы толщиной 5-10 мкм готовили на санном микротоме МПС-2 (Россия), толщиной 10-15 мкм - на замораживающем микротоме М3-2 (Россия), окрашивали гематоксилином и эозином для изучения общей гистологической структуры. Полученные препараты просматривали под микроскопом (МБС-10, ОАО «ЛЗОС», Россия) при увеличении $\times 4, \times 10, \times 40, \times 100$ (объектив) и $\times 10$ (окуляр). На препаратах методом треугольника определяли количественное соотношение тканей (железистой, жировой и соединительной). С помощью рисовального аппарата измеряли диаметр молочных альвеол, толщину соединительнотканных тяжей, подсчитывали число клеток железистого эпителия на 1 мм²$^{2}$. Для оценки тканевых структур препараты заливали в парафин по общепринятой методике и готовили парафиновые срезы на микротоме МПС-2. Гистологическое исследование выполнено в КабардиноБалкарского патологоанатомического бюро Министерства здравоохранения КБР.

В СПК им. В.И. Ленина и ООО «Эльбрус Агроинвест» исследовали по 5 гистологических срезов от каждой группы коров и ячих, в фермерском хозяйстве «Сарский» и селе Арик - по 3 гистосреза от коз зааненской породы и местных особей.

Для оценки биомеханических свойств на основании определения эластичности, упругости и прочности отбирали образцы тканей в центральной области подвешивающей связки. Испытания 6 образцов от двух групп коз - местной популяции и зааненской породы проводили на универсальной разрывной машине РЭМ-50-А (ООО «Метротест», Россия).

Биометрическую обработку данных выполняли согласно описанию (37). Рассчитывали средние арифметические $(M)$, стандартные ошибки средних $( \pm \mathrm{SEM})$, достоверность различий между средними величинами оценивали по $t$-критерию Стьюдента при трех уровнях доверительной вероятности (P > 0,95; $\mathrm{P}>0,99$ и $\mathrm{P}>0,999)$.

Результаты. Мониторинг микроструктуры молочной железы у обследованных животных показал разное соотношение типов тканей в зависимости от породной (генотипической) принадлежности особей (табл. 1).

Бо́льшую долю железистой ткани отмечали у помесей голштинов и черно-пестрого скота в $\mathrm{F}_{2}$ с превосходством над одноименными сверстницами в $\mathrm{F}_{1}$ на $3,1 \%$ ( $\left.\mathrm{P}>0,95\right)$, над чистопородными черно-пестрыми коровами - на 8,3\% (P > 0,99). При сравнении швицкого и голштиношвицкого скота доля железистой ткани оказалась выше у помесей (на 4,5-7,9 \%, P > 0,95-0,99). У коров $\mathrm{F}_{2}$ из-за увеличения количества железистой ткани снизилась доля соединительной и жировой. Так, соединительной ткани у швицев было на 4,0-6,5 \% больше (P > 0,95), чем у помесных голштино-швицких сверстниц в $\mathrm{F}_{1}$ и $\mathrm{F}_{2}$, жировой - на 0,5-1,4 \%. Аналогичные различия отмечали в распределении этих тканей между черно- 
пестрыми коровами и помесями голштинов с черно-пестрым скотом. У представительниц швицкой породы бо́льшая доля жировой ткани в вымени, вероятно, связана с лучшей предрасположенностью этой породы к синтезу молочного жира.

1. Соотношение типов тканей в молочной железе у коров 2-го отела в зависимости от происхождения ( $M \pm \mathrm{SEM}$, Кабардино-Балкарская Республика, Урванский р-н, СПК им. В.И. Ленина, 2012-2015 годы)

\begin{tabular}{c|c|c|c}
\hline \multirow{2}{*}{ Группа $(n=5)$} & \multicolumn{3}{|c}{ Тип ткани в молочной железе } \\
\cline { 2 - 4 } & железистая & соединительная & жировая \\
\hline I & $66,7 \pm 1,20$ & $23,2 \pm 1,13$ & $10,1 \pm 0,67$ \\
II & $71,2 \pm 0,93^{*}$ & $19,2 \pm 1,21^{*}$ & $9,6 \pm 0,80$ \\
III & $74,6 \pm 1,10^{* *}$ & $16,7 \pm 1,68^{*}$ & $8,7 \pm 1,04$ \\
IV & $68,4 \pm 1,32$ & $21,9 \pm 0,98$ & $9,7 \pm 0,59$ \\
V & $73,6 \pm 0,85^{*}$ & $17,2 \pm 1,75^{*}$ & $9,2 \pm 0,73$ \\
VI & $76,7 \pm 1,04^{* *}$ & $15,3 \pm 1,87^{*}$ & $8,0 \pm 0,92$ \\
\hline
\end{tabular}

П р и м е ч н и е. I - швицы; II - голштины $\times$ швицы, $\mathrm{F}_{1}$; III - голштины $\times$ швицы, F пестрые; V - голштины $\times$ черно-пестрая порода, $\mathrm{F}_{1}$; VI - голштины $\times$ черно-пестрая порода, $\mathrm{F}_{2}$.

*, ** Различия статистически значимы соответственно при $\mathrm{P}>0,95$ и $\mathrm{P}>0,99$ (для II и III групп относительно I группы, для V и VI - относительно IV).

Исследования гистоструктуры выявили у коров черно-пестрой, бурой швицкой пород и их голштинизированных помесей отличительные особенности в строении молочной железы во все возрастные периоды (табл. 2).

2. Гистоструктура молочной железы коров в зависимости от породы и возраста ( $M \pm \mathrm{SEM}$, CПК им. В.И. Ленина, Урванский р-н, Кабардино-Балкарская Республика, 2012-2015 годы)

\begin{tabular}{|c|c|c|c|c|c|c|c|}
\hline \multirow{2}{*}{$\begin{array}{l}\text { Группа } \\
(n=5)\end{array}$} & \multirow[b]{2}{*}{ Отел } & \multicolumn{2}{|c|}{ Диаметр, мкм } & \multicolumn{3}{|c|}{ Толщина соединительнотканных тяжей, мкм } & \multirow{2}{*}{$\begin{array}{l}\text { Число кле- } \\
\text { ток эпите- } \\
\text { лия на } 1 \text { мм² }\end{array}$} \\
\hline & & альвеол & $\begin{array}{l}\text { жировых } \\
\text { клеток }\end{array}$ & магистральных & $\begin{array}{l}\text { междоль- } \\
\text { ковых }\end{array}$ & $\begin{array}{l}\text { внутридоль- } \\
\text { ковых }\end{array}$ & \\
\hline \multirow[t]{3}{*}{ I } & 1-й & $73,5 \pm 1,32$ & $70,4 \pm 0,68$ & $471,3 \pm 6,09$ & $84,3 \pm 1,47$ & $30,3 \pm 1,08$ & $3,56 \pm 0,11$ \\
\hline & 2 -й & $80,0 \pm 0,41$ & $72,6 \pm 2,10$ & $480,3 \pm 4,26$ & $88,6 \pm 1,77$ & $31,0 \pm 1,41$ & $3,76 \pm 0,10$ \\
\hline & 3-й & $89,0 \pm 1,41$ & $78,3 \pm 1,47$ & $492,3 \pm 6,17$ & $91,0 \pm 0,41$ & $34,0 \pm 0,70$ & $4,06 \pm 0,14$ \\
\hline \multirow[t]{3}{*}{ II } & $1-и ̆$ & $90,3 \pm 1,77^{* * *}$ & $72,3 \pm 1,47$ & $530,0 \pm 6,28^{* * *}$ & $70,6 \pm 1,77^{* *}$ & $29,0 \pm 1,41$ & $3,80 \pm 0,14$ \\
\hline & 2-й & $97,3 \pm 1,78^{* * *}$ & $78,0 \pm 2,54$ & $534,3 \pm 5,75^{* * *}$ & $74,0 \pm 1,41^{* * *}$ & $31,0 \pm 0,41$ & $3,93 \pm 0,08$ \\
\hline & 3-й & $112,0 \pm 2,54^{* * *}$ & $80,6 \pm 1,78$ & $550,0 \pm 6,36^{* * *}$ & $77,3 \pm 1,47^{* * *}$ & $33,0 \pm 0,07$ & $4,03 \pm 0,14$ \\
\hline \multirow[t]{3}{*}{ III } & $1-и ̆$ & $101,3 \pm 4,60^{* * *}$ & $74,3 \pm 2,85$ & $539,0 \pm 8,33^{* * *}$ & $68,0 \pm 4,24^{* * *}$ & $29,3 \pm 2,48$ & $3,90 \pm 0,21$ \\
\hline & $2-и ̆$ & $116,0 \pm 4,24^{* * *}$ & $76,0 \pm 3,94$ & $555,3 \pm 11,66^{* * *}$ & $70,0 \pm 3,24^{* * *}$ & $30,7 \pm 2,48$ & $4,10 \pm 0,20$ \\
\hline & 3-й & $119,0 \pm 4,95^{* * *}$ & $80,4 \pm 6,30$ & $570,0 \pm 8,86^{* * *}$ & $77,0 \pm 4,41^{* *}$ & $34,3 \pm 2,58$ & $4,23 \pm 0,20$ \\
\hline \multirow[t]{3}{*}{ IV } & 1-й & $74,0 \pm 1,41$ & $68,3 \pm 1,47$ & $467,0 \pm 4,30$ & $79,0 \pm 1,41$ & $32,0 \pm 0,71$ & $3,50 \pm 0,12$ \\
\hline & 2-й & $79,0 \pm 1,40$ & $70,0 \pm 1,22$ & $480,0 \pm 3,53$ & $80,3 \pm 1,47$ & $33,0 \pm 0,70$ & $3,60 \pm 0,12$ \\
\hline & 3-й & $90,0 \pm 1,87$ & $73,0 \pm 1,41$ & $491,0 \pm 1,13$ & $88,0 \pm 0,41$ & $35,0 \pm 0,70$ & $3,80 \pm 0,13$ \\
\hline \multirow[t]{3}{*}{$\mathrm{V}$} & 1-й & $90,3 \pm 2,16^{* * *}$ & $68,6 \pm 1,77$ & $495,0 \pm 6,81^{* *}$ & $70,0 \pm 1,87^{* *}$ & $31,0 \pm 1,41$ & $3,66 \pm 0,10$ \\
\hline & 2 -й & $99,6 \pm 2,48^{* * *}$ & $73,3 \pm 2,16$ & $502,0 \pm 7,64^{*}$ & $72,0 \pm 2,12^{*}$ & $31,3 \pm 1,47$ & $3,80 \pm 0,12$ \\
\hline & 3-й & $110,6 \pm 2,48^{* * *}$ & $77,3 \pm 2,16$ & $515,0 \pm 5,33^{* *}$ & $76,3 \pm 1,77^{* * *}$ & $34,0 \pm 1,41$ & $4,00 \pm 0,12$ \\
\hline \multirow[t]{3}{*}{ VI } & $1-и ̆$ & $111,0 \pm 3,53^{* * *}$ & $70,3 \pm 2,48$ & $520,0 \pm 7,07^{* * *}$ & $65,0 \pm 2,12^{* * *}$ & $30,0 \pm 1,87$ & $3,90 \pm 0,14$ \\
\hline & 2 -й & $115,0 \pm 3,93^{* * * *}$ & $75,0 \pm 2,82$ & $540,0 \pm 7,87^{* * *}$ & $69,0 \pm 2,82^{* *}$ & $32,0 \pm 2,12$ & $3,90 \pm 0,18$ \\
\hline & 3-й & $118,0 \pm 3,24^{* * *}$ & $77,3 \pm 2,16$ & $556,0 \pm 8,83^{* * *}$ & $75,0 \pm 2,54^{* *}$ & $33,0 \pm 1,41$ & $4,10 \pm 0,14$ \\
\hline & & 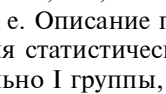 & ? & (3) & , & , & (Д \\
\hline
\end{tabular}

Мы установили, что независимо от породной принадлежности и генотипа коров значения всех анализируемых показателей с возрастом увеличиваются. При прочих равных условиях они были выше в группах голштинизированных животных. Среди коров 1-го отела большим диаметром альвеол выделялись помеси $F_{2}$ голштинов со швицами и с чернопестрым скотом, у которых различия со сверстницами материнской породы составили соответственно 27,8 мКм (P > 0,999) и 37,0 мкм ( $\mathrm{P}>0,999)$, с особями 2-го отела - по 36,0 мкм (P > 0,999), 3-го - 30,0 мкм $(\mathrm{P}>0,999)$ и 28,0 мкм $(\mathrm{P}>0,999)$. Помесные животные $\mathrm{F}_{1}$, независимо от материнской породы, по этому признаку занимали промежуточное положение относительно крайних значений. Наибольший диаметр альвеол от- 
мечали у помесей $\mathrm{F}_{2}$ (швицы $\times$ голштины) 3-го отела -119 мкм, что выше аналогичного показателя у сверстниц из I, II, IV и V групп на 6,2$3,7 \%$ (P > 0,999). Различия по этому показателю между животными $\mathrm{F}_{2}$ из III и VI групп $(0,8$ \%) были недостоверными. Следует отметить, что максимальным увеличением диаметра альвеол от 1-го к 3-му отелу характеризовались полукровные помеси голштины $\times$ швицы $(+21,7$ мкм, $\mathrm{P}>0,999)$ и голштины $\times$ черно-пестрый скот $(+20,3$ мкм, P > 0,999).

Наименьшим диаметром жировых клеток в 1-ю лактацию характеризовались коровы черно-пестрой породы (68,3 мкм), наибольшим - $1 / 2^{-}$и $3 / 4^{-}$ кровные помеси голштины $\times$ швицы $\left(\mathrm{F}_{1}\right.$ и $\left.\mathrm{F}_{2}\right)$ (соответственно 72,3 и 74,3 мкм), все остальные группы занимали промежуточное положение. Подобные тенденции сохранялись в возрасте 2-й и 3-й лактаций. В большей степени возрастное увеличение диаметра жировых клеток было свойственно помесям голштины $\times$ черно-пестрый скот в $\mathrm{F}_{2}$ с варьированием от 70,3 мкм у первотелок до 77,3 мкм у животных 3-го отела.

Эти данные о различиях в гистоструктуре молочной железы между отечественными породами и их помесями, полученными от использования генофонда улучшающих молочных пород крупного рогатого скота, согласуются с результатами более ранних сообщений $(20,24)$.

Альвеолы и выводные протоки окружены собственно соединительной тканью. Проникая между долями, дольками и альвеолами, соединительная ткань образует ячеистую сеть, состоящую из тяжей и прослоек (1). На основании проведенных нами исследований можно заключить, что с возрастом толщина соединительнотканных тяжей увеличивалась во всех группах молочного скота, причем в наибольшей степени это было характерно для магистральных тяжей, в наименьшей - для внутридольковых. При сравнении показателей у черно-пестрых коров и помесей голштинов с черно-пестрым скотом оказалось, что более толстые магистральные тяжи (независимо от номера лактации) свойственны коровам в $\mathrm{F}_{2}$, чье превосходство над чистопородными сверстницами составило по отелам 53 мкм $(\mathrm{P}>0,999), 60$ мкм $(\mathrm{P}>0,999)$ и 65 мкм $(\mathrm{P}>0,999)$. У помесей голштинов со швицами $\left(\mathrm{F}_{2}\right)$ эти тяжи были толще в 3-ю лактацию (с превышением на 2,5-16,0\% относительно остальных групп).

Несколько иную тенденцию выявили при анализе толщины междольковых тяжей: с возрастом она возрастала, а повышение кровности по голштинам обусловило снижение этого показателя. Так, в $\mathrm{F}_{1}$ и $\mathrm{F}_{2}$ у помесей голштины $\times$ швицы толщина междольковых тяжей с возрастом увеличилась с 68,0 до 77,3 мкм, у помесей голштины $\times$ черно-пестрый скот - с 65,0 до 76,3 мкм. Отметим, что во все лактации бо́льшая толщина междольковых соединительнотканных тяжей была характерны для чистопородных бурых швицких и черно-пестрых особей. Соответствующее превосходство швицких коров над голштино-швицкими составило по 1-му отелу 13,7-16,3 мкм (P > 0,99-0,999), по 2-му - 14,6-18,6 мкм ( $>$ > 0,999), по 3 -му - 13,7-14,0 мкм (P > 0,99-0,999). Подобные различия имели место между группами черно-пестрого и помесного голштинизированного черно-пестрого скота с превосходством коров черно-пестрой породы.

Варьирование диаметра внутридольковых тяжей было несколько ниже, чем магистральных и междольковых: у коров всех изученных генотипов, независимо от номера лактации, величина этого показателя находилась в пределах 29,0-35,0 мкм и с повышением кровности по голштинской породе изменялась незначительно.

Число клеток эпителия на 1 мм² площади альвеол было наимень- 
шим у первотелок черно-пестрой породы, наибольшим - у животных $\mathrm{F}_{2}$, независимо от того, какая порода использовалась в качестве материнской. Так, различия между швицкими и голштино-швицкими первотелками по этому показателю составили 0,24-0,34 кл/мм² в пользу помесей, между черно-пестрыми и голштино-черно-пестрыми - 0,16-0,4 кл/мм². Превосходство помесей (разного генотипа) над чистопородными сверстницами

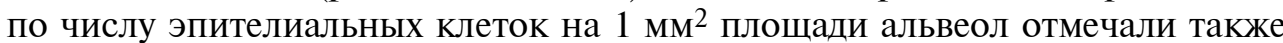
по 2-му и 3-му отелам.

Таким образом, изучение гистопрепаратов молочных желез помесных коров, полученных от скрещивания коров швицкой и черно-пестрой пород с быками голштинской породы черно-пестрой масти, свидетельствует, что по степени развития важнейших для секреции молока структурных элементов молочной железы улучшенные животные и особи исходных материнских пород различались. Размер молочных альвеол и диаметр жировых шариков у помесей был больше, чем у сверстниц бурой швицкой и черно-пестрой пород, причем эти показатели с повышением кровности по голштинской породе увеличивались при незначительном возрастном снижении толщины междольковых тяжей.

3. Соотношение типов ткани (\%) в молочной железе у коров бурой швицкой породы местной популяции и ячих, завезенных из Тувы и Киргизии (по $n=5$ в группе, $M \pm \mathrm{SEM}, \mathrm{OOO}$ «Эльбрус Агроинвест», Черекский р-н, Кабардино-Балкарская Республика, 2015-2016 годы)

\begin{tabular}{l|c|c|c}
\hline \multirow{2}{*}{ Тип ткани } & Бурые швицкие коровы & \multicolumn{2}{|c}{ Ячихи } \\
\cline { 3 - 4 } & местной популяции & завезены из Тувы & завезены из Киргизии \\
\hline Железистая & $64,3 \pm 1,30$ & $56,8 \pm 0,90^{*}$ & $54,6 \pm 0,70^{*}$ \\
Соединительная & $25,1 \pm 0,50$ & $30,8 \pm 0,60^{*}$ & $30,9 \pm 0,60^{*}$ \\
Жировая & $10,6 \pm 0,20$ & $12,4 \pm 0,10^{*}$ & $14,5 \pm 0,20^{*}$ \\
П р и м е ч а н и е. Обследованы животные 3-го отела. \\
* Различия с показателями у коров бурой швицкой породы статистически значимы соответственно при \\
Р >0,999.
\end{tabular}

Сравнение типов ткани в молочной железе коров швицкой породы местной популяции и ячих, завезенных из Тувы и Киргизии, показало (табл. 3), что у ячих из разных популяций доля соединительной ткани практически одинакова - 30,8-30,9 \%, что на 5,7-5,8 \% больше, чем у сверстниц бурой швицкой породы $(\mathrm{P}>0,999)$. Однако завезенные в регион ячихи уступали швицам местной популяции по относительному количеству железистой ткани (по этому показателю обычно судят о молочности маток). Различия по доле железистой ткани между швицкими коровами и ячихами варьировали в пределах 7,5-9,7 \% (Р > 0,999). По количеству жировой ткани в молочной железе первенствовали ячихи из Киргизии с превышением показателя на 2,1 \% (P > 0,999) относительно такового у сверстниц из Тувы и на 3,9 \% (P > 0,999) - у бурых швицев местной популяции, что объясняет более высокую жирномолочность ячих.

Сопоставление гистоструктуры вымени в возрасте 3-го отела у ячих и коров швицкой породы местной популяции показало (табл. 4), что диаметр альвеол у местных швицев больше, чем у ячих (независимо от происхождения последних; в среднем превышение на 9,1-11,3 мкм, Р > 0,999), что свидетельствует о несущественных различиях по этому показателю между ячихами разного происхождения и преимуществе коров двойного направления использования. Диаметр жировых клеток у ячих был в среднем на 4,5-5,4 мкм (Р > 0,99) больше, чем у сверстниц швицкой породы. Более развитые жировые клетки молочной железы обусловливают высокие показатели качества молока у ячих. 
4. Гистоструктура молочной железы у коров бурой швицкой породы местной популяции и ячих, завезенных из Тувы и Киргизии (по $n=5$ в группе, ООО «Эльбрус Агроинвест», Черекский р-н, Кабардино-Балкарская Республика, 2015-2016 годы)

\begin{tabular}{l|c|c|c}
\hline \multicolumn{1}{c}{ Показатель } & Бурые швицкие коровы & \multicolumn{2}{|c}{ Ячихи } \\
\cline { 3 - 4 } & местной популяции & завезены из Тувы & завезены из Киргизии \\
\hline Диаметр, мкм: & $90,6 \pm 1,45$ & $79,3 \pm 1,22^{* * *}$ & $81,5 \pm 1,06^{* * *}$ \\
альвеол & $77,1 \pm 0,88$ & $82,5 \pm 1,03^{* *}$ & $81,6 \pm 0,90^{* *}$ \\
жировых клеток & $501,4 \pm 5,13$ & $472,5 \pm 3,96^{* * *}$ & $476,3 \pm 4,78^{* *}$ \\
Толщина тяжей, мкм: & $75,4 \pm 1,98$ & $93,0 \pm 2,46^{* * *}$ & $90,4 \pm 2,31^{* *}$ \\
$\quad$ магистральных & $33,4 \pm 1,36$ & $34,5 \pm 1,45$ & $34,1 \pm 1,60$ \\
междольковых & $4,20 \pm 0,08$ & $3,91 \pm 0,07^{*}$ \\
внутридольковых & $3,84 \pm 0,06^{* *}$ & \\
Число эпителиальных клеток & на 1 мм² поверхности альвеол
\end{tabular}

Толщина соединительнотканных тяжей варьировала в зависимости от происхождения животных. По анализируемым показателям соединительной ткани ячихи, завезенные из Тувы и Киргизии, различались незначительно. При этом толщина магистральных тяжей была больше у коров швицкой породы местной популяции (в среднем на 25,1-28,9 мкм), междольковых - у ячих (в среднем на 15,0-17,6 мкм) (Р > 0,99-0,999). Мы не выявили существенных различий по толщине внутридольковых тяжей между животными разного происхождения в этих группах. Число клеток желе-

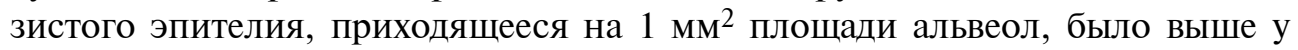
коров бурой швицкой породы местной популяции, чем у ячих разного происхождения (в среднем на 0,29-0,36 кл/мм², Р > 0,95-0,99).

Как и у крупного рогатого скота молочного направления продуктивности $(20,24,28)$, у молочных коз $(27,32,38)$ продуктивные качества во многом обусловлены развитием (гистогенезом) молочной железы, превалированием тех или иных тканей. Для сравнения мы изучили гистоструктуру и выполнили биомеханические испытания тканей молочной железы у коз разного происхождения (табл. 5).

5. Соотношение типов тканей, гистоструктура и биомеханические свойства молочной железы у коз разного происхождения (по $n=3$ в группе, $M \pm \mathrm{SEM}$, Кабардино-Балкарская Республика, 2016-2017 годы)

\begin{tabular}{l|c|c|c}
\hline \multirow{2}{*}{ Показатель } & \multicolumn{2}{c|}{ Порода, происхождение } & \multirow{2}{*}{ Зааненские козы в } \\
сравнении с местными
\end{tabular}


Анализ гистопрепаратов молочной железы коз выявил неодинаковое соотношение типов тканей. Так, у зааненских коз железистая ткань занимает наибольший объем - 65,3\%, что на 16,7 \% больше, чем у местных коз (Р > 0,999). Различия по содержанию собственно соединительной ткани между группами коз варьировали в пределах $1,9 \%(\mathrm{P}>0,95)$, при этом наилучшее соотношение паренхимы и стромы $(1,88: 1)$ отмечали в молочной железе коз зааненской породы (против 0,94:1 у коз местной популяции). В то же время жировая ткань оказалась менее развита в железе молочных зааненских коз (в среднем на 18,6 \%, Р > 0,999). Большим диаметром альвеол (на 15,9 мкм, Р > 0,99) характеризовались козы зааненской породы, тогда как по площади жировых клеток существенных межгрупповых различий мы не выявили. Между козами разного происхождения имелись различия по толщине соединительнотканных тяжей, особенно магистральных и междольковых, с превышением этих показателей у особей зааненской породы соответственно на 13,9 мкм (P > 0,999) и 6,6 мкм $(\mathrm{P}>0,99)$.

Максимальные показатели прочности, упругости и эластичности тканей молочной железы в центральной области подвешивающей связки были характерны для образцов от зааненских коз. Так, их преимущество составило по пределу прочности 1,4 МПа (Р > 0,99), по модулю упругости - 551 МПа (Р> 0,999), по максимальной упругой деформации $-1,9 \%$ $(\mathrm{P}>0,95)$. Более высокие биомеханические свойства молочной железы у зааненских коз по сравнению с местными особями, по-видимому, обусловлены селекцией заводских пород одновременно на молочную продуктивность и по морфофункциональным свойствам вымени.

Итак, результаты анализа гистоструктуры и свойств молочной железы крупного рогатого скота, яков и коз позволяют сделать следующие выводы. Улучшенные голштинами животные по доле железистой ткани в молочной железе, степени развития и размеру важнейших для секреции молока структурных элементов (молочные альвеолы, жировые шарики) превосходят сверстниц бурой швицкой и черно-пестрой пород. Сравнение молочной железы бурого швицкого скота и ячих, завезенных из Тувы и Киргизии, выявило следующие характерные особенности: у швицев местной популяции больше число клеток железистого эпителия, диаметр альвеол и толщина магистральных тяжей, тогда как у ячих разных популяций повышена доля жировой ткани, меньше диаметр жировых клеток и больше толщина междольковых тяжей. Среди коз разного происхождения более развитой молочной железой с высокими биомеханическими свойствами выделяются особи зааненской породы. Независимо от видовой принадлежности, более обильномолочные животные отличались от менее продуктивного скота преобладанием в молочной железе железистой ткани, клеток эпителия, большей толщиной магистральных тяжей и улучшенными биомеханическими свойствами тканей.

\section{ЛИТЕРАТУРА}

1. Гузеев Ю.В. Секреторная функция и емкостная система вымени буйволиц. Технологія виробництва і переробки продукції тваринництва, 2014, 1(110): 52-57.

2. Климов Н.Т., Зимников В.И. Защита здоровья молочной железы коров: ветеринарнотехнологические аспекты. Молочная промышленность, 2015, 10: 69-70.

3. Tyshkivska N., Sahnyuk N., Tyshkivskiy M. Physicochemical and microbiological indicators of mammary gland secretion of cows with different number of somatic cells. Науковий вісник ветеринарної медицини, 2015, 2(122): 31-36.

4. Лискун Е.Ф. Строение молочной железы в связи с количеством производимого молока. Труды Бюро по зоотехнии, 1912, 8: 26-84. 
5. Santos D.B., Vanin J., Silva C.G. Milk quality of family farms practicing crop-livestock integration depending on land use. Agr. Brasil. Med. Vet. Zootechn., 2013, 65(4): 1217-1222 (doi: 10.1590/S0102-09352013000400038).

6. Давыдова Т.Г., Дроздова Л.И. Сравнительная морфология молочной железы высокопродуктивных коров при нисходящем и восходящем маститах. Аграрный вестник Урала, 2011, 9(88): 20-22.

7. Van der Zwaag H.G., Van Schaik G., Lam T.J.G.M. Mastitis control program in the Netherlands: goal, tools and conditions. 4th IDF Int. Mastitis Conference. Academic Publishers, Wageningen, the Netherlands, 2005: 599-604.

8. Huijps K., Lam T., Hogeveen H. Costs of mastitis: facts and perception. Journal of Dairy Research, 2008, 75: 113-120 (doi: 10.1017/S0022029907002932).

9. Bar D., Grohn Y.T., Bennett G., Gonzalez R.N., Hertl J.A., Schulte H.F., Tauer L.W., Welcome F.L., Schukken Y.H. Effects of repeated episodes of generic clinical mastitis on mortality and culling in dairy cows. Journal of Dairy Science, 2008, 91(6): 2196-2204 (doi: 10.3168/jds.2007-0460).

10. Шабунин С.В. Новые подходы к решению проблемы незаразных патологий животных в современном молочном скотоводстве. Ученые записки учреждения образования Витебская ордена Знак почета государственная академия ветеринарной медицины, 2017, 53(2): 149-151.

11. Батраков А.Я. Профилактика маститов у коров. Ученые записки учреждения образования Витебская ордена Знак почета государственная академия ветеринарной медицины, 2011, 47(2): 10-11.

12. Mitev J., Gergovska I., Miteva M. Effect of teat end hyperkeratosis on milk somatic cell counts in Bulgarian Black-and-White dairy cattle. Bulgarian Journal of Agricultural Science, 2012, 18: 451-454.

13. Asadpour R., Bagherniaee H., Houshmandzad M., Fatehi H., Rafat A., Nofouzi K., Maftouni K. Relationship between teat end hyperkeratosis with intra mammary infection and somatic cell counts in lactating dairy cattle. Revue de Medecine Veterinaire, 2015, 166: 266-270.

14. Колчина А.Ф., Баркова А.С., Барашкин М.И. Современные методы в диагностике патологии молочной железы высокопродуктивных коров. Аграрный вестник Урала, 2012, 12: 12-14.

15. Knight C.H., Wilde C.J. Mammary cell changes during pregnancy and lactation. Livestock Production Science., 1993, 35(1-2): 3-19 (doi: 10.1016/0301-6226(93)90178-K).

16. Alvi A.J., Clayton H., Joshi C., Enver T., Ashworth A., Vivanco M.dM, Dale T.C., Smalley M.J. Functional and molecular characterisation of mammary side population cells. Breast Cancer Research, 2003, 5(1): R1-R8 (doi: 10.1186/bcr547).

17. Smith G.H., Chepko G. Mammary epithelial stem cells. Microsc. Res. Tech., 2001, 52(2): $190-$ 203 (doi: 10.1002/1097-0029(20010115)52:2<190::AID-JEMT1005>3.0.CO;2-O).

18. Kordon E.C., Smith G.H. An entire functional mammary gland may comprise the progeny from a single cell. Development, 1998, 125: 1921-1930.

19. Есмагамбетов К.К. Функциональные свойства вымени коров разного генотипа и уровня продуктивности при асинхронном доении. Главный зоотехник, 2013, 8: 15-19.

20. Сулейманов С.М., Павленко О.Б., Миронова Л.П., Паршин П.А. Морфология молочной железы и клеточный состав молока у здоровых коров в период лактации. Актуальные вопросы ветеринарной биологии, 2017, 3(35): 44-49.

21. Besier J., Bruckmaier R.M. Vacuum levels and milk-flow-dependent vacuum drops affect machine milking performance and teat condition in dairy cows. Journal of Dairy Science, 2016, 99(4): 3096-3102 (doi: 10.3168/jds.2015-10340).

22. Edwards J.P., O'Brien B., Lopez-Villalobos N., Jago J.G. Overmilking causes deterioration in teatend condition of dairy cows in late lactation. Journal of Dairy Research, 2013, 80(3): 344348 (doi: 10.1017/S0022029913000307).

23. Sterrett A.E., Wood C.L., Mc.Querry K.J., Bewley J.M. Changes in teat-end hyperkeratosis after installation of an individual quarter pulsation milking system. Journal of Dairy Science, 2013, 96(6): 4041-4046 (doi: 10.3168/jds.2012-6069).

24. Ferneborg S., Svennersten-Sjaunja K. The effect of pulsation ratio on teat condition, milk somatic cell count and productivity in dairy cows in automatic milking. Journal of Dairy Research, 2015, 82(4): 453-459 (doi: 10.1017/S0022029915000515).

25. Rasmussen M.D., de Blom J.Y., Nielsen L.A.H., Justesen P. The impact of automatic milking on udder health. Proceedings of the 2-nd International Symposium on Mastitis and Milk Quality, NMC/AABP. Vancouver, 2001: 397-400.

26. Mein G.A., Williams D.M.D., Reinemann J. Effect of milking on teat-end hyperkeratosis: Mechanical forces applied by the teatcup liner and responses of the teat. Proc. 42nd Animal Meeting of the National Mastitis Council. USA, Fort Worth, Texas, 2003: 114-123.

27. Götze A., Honnens A., Flachowsky G., Bollwein H. Variability of mammary blood flow in lactating Holstein-Friesian cows during the first twelve weeks of lactation. Journal of Dairy Science, 2010, 93(1): 38-44 (doi: 10.3168/jds.2008-1781).

28. Тузов И.Н., Турлюн В.И. Морфофизиологические свойства молочной железы айршир- 
ской породы. В сб.: Научные основы повышения продуктивности сельскохозяйственных животных. Краснодар, 2009: 130-132.

29. Бармин С.В., Горбунова Н.Л., Олейникова Е.В., Соловьёва Л.П. Интерьер молочной железы у 16-месячных телок костромской породы. Иппология и ветеринария, 2011, 2: 89-92.

30. Чикалев А.И., Юлдашбаев Ю.А. Овцеводство. М., 2015.

31. Горбунова Н.П., Соловьева Л.П. Морфогенез молочной железы лактирующих овцематок романовской породы в условиях АОЗТ «Родина» Судиславского района. Иппология и ветеринария, 2011, 1: 81-83.

32. Щипакин М.В. Структурная организация молочной железы у лактирующих коз зааненской породы. Вопросы нормативно-правого регулирования в ветеринарии, 2013, 3: 136-137.

33. Баркова А.С., Шурманова Е.И. Сравнительная оценка влияния роботизированной системы доения на состояние молочной железы высокопродуктивных коров. Ученые записки учреждения образования Витебская ордена Знак почета государственная академия ветеринарной медицины, 2017, 53(2): 166-169.

34. Тамарова Р.В. Адаптация коров голштинской породы канадской селекции в условиях молочного комплекса с привязным содержанием животных. Вестник АПК Верхневолжья, 2016, 3(35): 41-47.

35. Tse C., Barkema H.W., DeVries T.J., Rushen J., Pajor E.A. Effect of transitioning to automatic milking systems on producers' perceptions of farm management and cow health in the Canadian dairy industry. Journal of Dairy Science, 2016, 100(3): 2404-2414 (doi: 10.3168/jds.2016-11521).

36. Penry J.F. Mastitis control in automatic milking systems. Veterinary Clinics of North America: Food Animal Practice, 2018, 34(3): 439-456 (doi: 10.1016/j.cvfa.2018.06.004).

37. Плохинский Н.А. Руководство по биометрии для зоотехников. М., 1969.

38. Trzewik Ju., Mallipattu S.K., Artmann G.M., Delano F.A., Schmid-Schonbein G.W. Evidence for a second valve system in lymphatics: endothelial microvalves. The FASEB Journal, 2001, 15(10): 1711-1717 (doi: 10.1096/fj.01-0067com).

\footnotetext{
${ }^{1}$ Северо-Кавказский федеральный научный аграрный иентр,

356241 Россия, Ставропольский край, г. Михайловск, ул. Никонова, 49,

e-mail: info@fnac.center, murat-ul@yandex.ru $₫$;

${ }^{2}$ Кабардино-Балкарский государственный аграрный

университет им. В.М. Кокова,

360030 Россия, Кабардино-Балкарская Республика, г. Нальчик,

просп. В.И. Ленина, 1в,

e-mail: getokov777@mail.ru, ulimbasheva1976@mail.ru
}

Поступила в редакцию

Sel'skokhozyaistvennaya biologiya [Agricultural Biology], 2019, V. 54, № 4, pp. 732-743

\title{
AGE VARIABILITY OF MAMMARY GLAND HISTOSTRUCTURE IN DAIRY AND NON-DAIRY ANIMALS OF DIFFERENT BREEDS AND ORIGIN
}

\author{
M.B. Ulimbashev', O.O. Getokov², V.V. Kulintsev' ${ }^{1}$, R.A. Ulimbasheva ${ }^{2}$
}

\begin{abstract}
${ }^{1}$ North-Caucasian Federal Scientific Agrarian Center, 49, ul. Nikonova, Mikhailovsk, Stavropol Krai, 356241 Russia, e-mailinfo@fnac.center, murat-ul@yandex.ru ( $\square$ corresponding author);

${ }^{2}$ Kokov Kabardino-Balkarian State Agrarian University, 1v, prosp. V.I. Lenina, Nal'chik, Kabardino-Balkarian Republic, 360030 Russia, e-mail getokov777@mail.ru, ulimbasheva1976@mail.ru
\end{abstract}

ORCID:

Ulimbashev M.B. orcid.org/0000-0001-9344-5751

Getokov O.O. orcid.org/0000-0001-8252-5246

The authors declare no conflict of interests

Received September 25, 2018

Kulintsev V.V. orcid.org/0000-0003-2482-6336

Ulimbasheva R.A. orcid.org/0000-0003-1755-2672

doi: 10.15389/agrobiology.2019.4.732eng

\section{Abstract}

Increase in milk production and improvement of milk quality must be addressed, along with of paratypic factors, through further researches of breast morphology and physiology. These studies are targeted not only at its morphological and functional characterization, but also at establishing basis for changing the body's activities and improvement of dairy animals. For most dairy breeds in the process of breeding almost reached the biological threshold of productivity. In addition, with the development of highly mechanized and automated technologies for milk production, the requirements for the selection of animals for adaptation to such conditions, in particular for the state of the udder, have increased. Therefore, an additional reserve can be the improvement of dairy cattle and improve the quality of milk on the basis of in-depth studies of the morphological, functional characteristics and physiology of the breast. The most informative data are presented on the structure and 
function of the udder in species with high initial milk yield and high quality indicators in comparison to the most common breeds of cattle. In the scientific literature there are no comparative data on histological mammary gland of cows and female-yaks. The results presented by us in this study fill this gap. Investigations of histostructure of udder in cows were carried out on black-motley and Brown Swiss breeds and their crosses with Holsteins ( $F_{1}$ and $F_{2}$, Lenin APS Farm), and on the local population of Brown Swiss cows and female-yaks imported from Tuva and Kyrgyzstan (LLS "Elbrus Agroinvest" farm). The microstructure was investigated using $2 \times 3 \mathrm{~cm}^{2}$ specimens taken between dairy base and the base of the tank throughout the udder fraction along a line passing through the center of the teat canal and lactic sinus in the right front of teat. In the mammary gland of $1 / 2$ Holstein-Swiss crossbred cows the diameter of alveoli were the largest and reached $119 \mu \mathrm{m}$ in the cows of the third lactation, which is $6,2-3,7 \%$ higher compared to peers of other groups $(\mathrm{P}>0.999)$. The smallest diameter of the fat cells are in the black-motley cows $(68.3 \mu \mathrm{m})$ and the largest ones were in Holstein-Swiss crossbred hybrids of the third lactation, the rest of cows take an intermediate position. The greatest increase in the diameter of the fat cells with age was in Holstein $\times$ black-motley hybrids $F_{2}$ in which the figure ranges from $68.6 \mu \mathrm{m}$ in heifers to $77.3 \mu \mathrm{m}$ in cows of the third calving. Consequently, according to the development and size of structure elements most important for milk production (the size of the alveoli, and the diameter of the fat globules), the animals improved by Holsteins are superior to the peers of pure Brown Swiss and black-motley cows. It was established that in local Brown Swiss cows the alveoli diameter is higher than that of female-yaks, regardless of their origin, and averages 9.1-11.3 $\mu \mathrm{m}$. By the fat cell diameter, the female-yaks were superior to the Brown Swiss peers by 4.5-5.4 $\mu \mathrm{m}$ on average. Thus, mammary glands of Brown Swiss cows and female-yaks imported from Tuva and Kyrgyzstan have characteristics features, namely Brown Swiss cows of local population have larger quantity of glandular epithelial cells, the diameter of alveoli, and the thickness of the main strands, whereas female-yaks have a higher concentration of adipose tissue, a smaller diameter of fat cells and the thickness of interlobular strands. For comparison, we compared the mammary gland in another animal species, the goats of different origin. It was shown that the Zaanen breed has better developed mammary gland with higher biomechanical properties as compared to the local goats' population.

Keywords: cows, yaks, goats, genotype, mammary gland, histological structure, alveoli, adipose cells, connective-woven strands.

\section{Научные собрания}

\section{$10^{\text {th }}$ INTERNATIONAL CONFERENCE ON FISHERIES \& AQUACULTURE}

(September 27-28, 2019, Toronto, Ontario, Canada

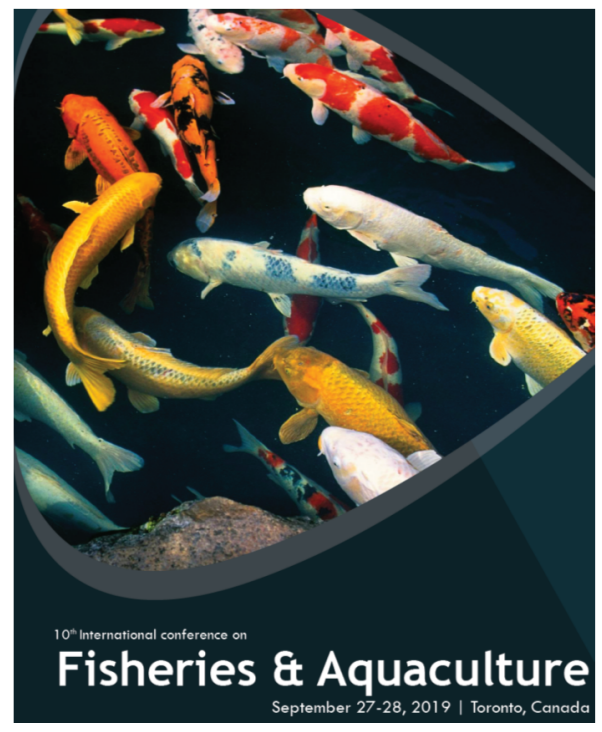

Themes:

- fish genetics \& biotechnology

- fish nutrition

- aquaculture methods

- nano aquaculture

- fish pathology \& physiology

- farming techniques

- aquaculture engineering

- fisheries conservation \& management

- fish freshwater fisheries

- aquatic ecology

- deep water \& demersal fisheries

- shellfish fisheries

- fisheries industries update fish

- sea food sustainability

- sea food handling

- fishing techniques

- marketing and pricing of fish

- aquatic immunology

- aquatic physiology

- aquatic toxicology

- aquaculture related diseases, health management

Information: https://fisheries.conferenceseries.com/, Contacts: fisheries@eventsupporting.org

EASTERN EUROPEAN REGIONAL VETERINARY CONFERENCE 2019

(October 3-5, 2019, Thessoliniki, Greece)

Information: https://eervc.vet 